Herviyani, et al/Jurnal Ekonomi Syariah Teori dan Terapan Vol. 6 No. 11 November 2019: 2158-2171; KOMPARASI BANK UMUM SYARIAH DI INDONESIA DAN MALAYSIA DITINJAU DARI RBBR DAN ISLAMICITY PERFORMANCE

\title{
KOMPARASI BANK UMUM SYARIAH DI INDONESIA DAN MALAYSIA DITINJAU DARI RBBR DAN ISLAMICITY PERFORMANCE'
}

\author{
Yunita Rahmania Herviyani \\ Departemen Ekonomi Syariah-Fakultas Ekonomi dan Bisnis-Universitas Airlangga \\ Email: yunita.rahmania.herviyani-2015@feb.unair.ac.id \\ Dian Filianti \\ Departemen Ekonomi Syariah-Fakultas Ekonomi dan Bisnis-Universitas Airlangga \\ Email: dianfilianti@feb.unair.ac.id
}

\begin{abstract}
:
To evaluate Islamic Bank for business continuity is usually measured by the Risk-Based Bank Rating (RBBR), But Islamic Bank as Islamic Business entities also need to be measured in terms of the Islamicity Performance. This study aims to analyze the comparison of Risk-Based bank Rating and Islamicity Performance of 11 Indonesian Islamic Banks and 11 Malaysian Islamic Banks. The Data collection in this research was done by collecting all the annual reports of Banks that has been created as sample over the period 2013-2018. The test result of the independent Samples T-test and Mann-Whitney Test show that there were no differences of Islamic Banks in Indonesia and Malaysia as seen from the aspect of FDR, ROA, CAR, and ZPR. While there were differences of Banks Health level and Islamicity Performance as seen from Earning (ROE) and Zakat Performance (ZPR) aspects.
\end{abstract}

Keywords: Bank Helath Level, Risk-Based Bank Rating, Islamicity Performance, Syariah Banking

\section{PENDAHULUAN}

Di dalam dunia perekonomian, sering kali berkaitan dengan peran lembaga keuangan khususnya perbankan. Perbankan dalam suatu negara memiliki peran strategis sebagai suatu agen pembangunan yang diharapkan dapat meingkatkan taraf hidup masyarakat banyak dengan cara menghimpun dana kemudian menyalurkan dana bagi pihak yang membutuhkan. Bank Syariah atau biasa disebut dengan Islamic Bank pada negara lain, berbeda dengan Bank Konvensional pada umumnya (Ascarya \& Diana, 2010:1).
Saat ini, globalisasi sangatlah penting untuk diwaspadai khususnya dalam globalisasi ekonomi. Bank Syariah sendiri sudah ada dan telah tumbuh di berbagai negara tidak hanya di Indoneisa maupun negara mayoritas muslim lainnya. Meski terdapat persaingan ketat dari Bank Konvensional, lembaga Islam telah terlihat peningkatan kesuksesannya, tidak hanya pada negara-negara Islam akan tetapi juga di negara-negara Barat yang maju termasuk Inggris dan Perancis. (Mansour, Ben Abdelhamid, Masood, \& Niazi, 2010).

\footnotetext{
${ }^{1}$ Jurnal ini merupakan bagian dari skripsi yang ditulis oleh Yunita Rahmania Herviyani, NIM: 041511433058, yang diuji pada 21 Oktober 2019.
} 


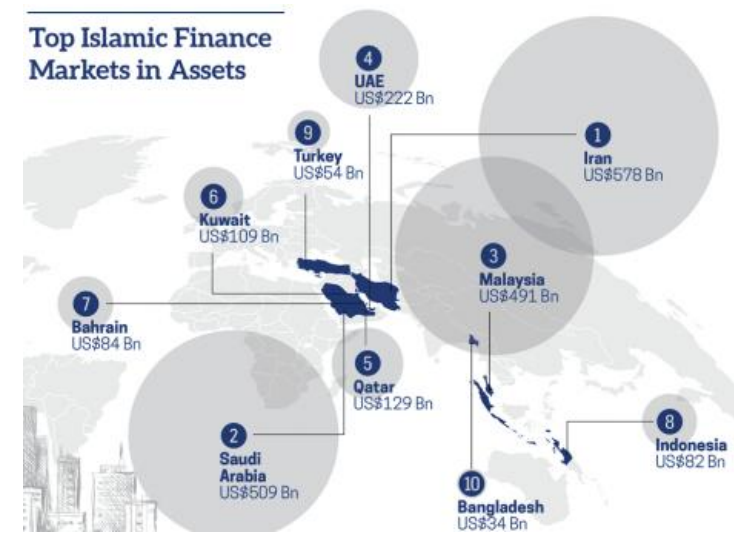

Sumber: Thomson Reuters

\section{Gambar 1.}

\section{Aset pasar Keuangan Syariah Terbaik}

Pada kawasan Negara Asia khususnya pada kawasan Asia Tenggara, wilayahnya termasuk wilayah yang menjadi pusat perkembangan industri kevangan dan Perbankan Syariah di dunia. Indonesia and Malaysia menjadi kunci penggerak utama perkembangan industri kevangan syariah di Asia Tenggara. (Rama, 2017). Malaysia merupakan negara yang memiliki aset terbaik ke-tiga dalam pasar keuangan syariah sedangkan Indonesia masuk dalam terbaik ke-delapan dalam aset pasar kevangan syariahnya.

$$
\text { Indonesia dan Malaysia }
$$

merupakan dua negara berpenduduk mayoritas muslim dan memiliki sistem yang sama yakni dual banking system. Dalam laporan Pew Research Center, lembaga riset global menyatakan pada tahun 2017 bahwa Indonesia merupakan negara berpopulasi muslim terbesar di dunia.

Ditinjau dari data OJK tahun 2018, market share Industri Perbankan Syariah di Indonesia masih relatif kecil yakni 5,70\%, sedangkan jika dilihat dari potensi bertumbuhnya, Indonesia memiliki peluang yang cukup baik untuk tumbuh. Sedangkan Malaysia, merupakan negara pertama di Asia Tenggara yang mengimplementasikan prinsip syariah dalam institusi keuangan syariahnya dan pertumbuhan Perbankan Syariah yang ada di Malaysia mengalami pertumbuhan yang fenomenal jika dibandingkan dengan negara lain. (Hendratmi, Sukmaningrum, \& Hasib, 2017)

Perkembangan Perbankan Syariah yang terus meningkat, harusnya diimbangi dengan kesehatan Bank Syariah yang baik guna mendapatkan kepercayaan para nasabah dalam dana yang diinvestasikannya. Untuk mewujudkan kepercayaan tersebut, dibutuhkan alat pengukur kesehatan dari Bank Syariah. Salah satu cara untuk mengetahui kesehatan Bank dan mengukur keadaan kevangan perusahaan ialah dengan cara menganalisis rasio keuangannya.

Sesuai dengan Undang-Undang Nomor 21 Tahun 2008 pasal 38 tentang Perbankan Syariah, bank wajib menerapkan manajemen risiko yakni serangkaian prosedur untuk mengidentifikasi, mengukur, memantau, dan mengendalikan risiko yang timbul dari kegiatan usaha Bank dalam hal ini untuk memelihara tingkat kesehatan Bank. Tingkat kesehatan Bank dengan metode Risk-Based Bank Rating (RBBR) ynag terdiri dari risk profile, Good Corporate Governance, Earning, dan Capital digunakan sebagai salah satu sarana 
Herviyani, et al/Jurnal Ekonomi Syariah Teori dan Terapan Vol. 6 No. 11 November 2019: 2158-2171; KOMPARASI BANK UMUM SYARIAH DI INDONESIA DAN MALAYSIA DITINJAU DARI RBBR DAN ISLAMICITY PERFORMANCE

evaluasi kondisi serta permasalahan yang dihadapi oleh Bank.

Faktor GCG dalam penelitian ini tidak diteliti dikarenakan adanya perbedaan dalam laporan GCG yang dikeluarkan pada bank Syariah Indonesia dan Malaysia. Laporan GCG pada bank di Indonesia dinilai berdasarkan setiap aspek yang terdapat di regulasi Bank Indonesai (PBI) no 13/1/PBI/2011 dengan menilai 11 aspek penilaian GCG. Sedangkan laporan GCG yang ada pada bank di Malaysia bertumpu dengan ketentuan GCG Malaysia, International Bank for International Settlement (BIS). (Hendratmi et al., 2017)(Hendratmi et al., 2017). Pada laporan GCG Bank Syariah di Malaysia bisa dilihat dalam annual report nya hanya berbentuk deskripsi, tidak menunjukkan angka maupun nilai dari tiap aspek seperti halnya laporan GCG yang dibuat oleh Bank Syariah di Indonesia.

Kinerja Bank Syariah rasanya tidak cukup jika hanya diukur dari aspek kesehatannya saja. Bank Syariah seharusnya harus dinilai lebih jauh dari risiko kredit dan tata kelola perusahaan, dan menetapkan kriteria yang lebih komprehensif untuk menilai stabilitaas mereka, salah satunya mengakui kredit yang sifatnya saling tergantung dan risiko fudisia. (Radzi \& Lonik, 2016)

Sebenarnya, telah ada beberapa penelitian yang berupaya membuat alat ukur yang telah disesuaikan dengan praktik dan karakteristik dari Bank Syariah salah satunya ialah Hameed et.al, (2004) Dalam penelitiannya, menghasilkan suatu penyajian alternative berupa suatu alat ukur yang dapat digunakan untuk mengukur kesyariahan suatu entitas bisnis syariah yang kemudian dinamakan Islamicity Index atau juga bisa dijuluki dengan Islamicity Performance. Index ini memiliki 6 rasio yang bisa diukur yakni Profit Sharing Ratio (PSR), Zakat Performance Ratio (ZPR), Equitable Distribution Ratio (EDR), DirectorsEmployee Welfare Ratio (DEWR), Islamic Investment vs Non Islamic Invesmtent (IIR), dan Isamic Income vs Non Islamic Income (ISIR).

Salah satu prinsip dalam kegiatan operasional Bank Syariah ialah penerapan bagi hasil dan risiko (Profit and Loss Sharing). Selain kinerja keislaman dalam bentuk rasio bagi hasil, terdapat indikator lain yang dapat diberikan kepada masyarakat salah satunya adalah zakat. Terdapat suatu ukuran dalam Islamicity Performance Index yang dapat digunakan untuk mengukur seberapa besar zakat yang dibayarkan oleh suatu perusahaan yakni Zakat Payment Ratio (ZPR).

Berdasarkan uraian di atas, untuk mengevaluasi Bank Syariah guna keberlangsungan bisnisnya biasa diukur dengan rasio kesehatan bank berbasis risiko (RBBR). Akan tetapi hal ini dirasa kurang, Bank Syariah sebagai entitas bisnis islam juga perlu diukur dari sisi sejauh mana kesyariahannya. 
Herviyani, et al/Jurnal Ekonomi Syariah Teori dan Terapan Vol. 6 No. 11 November 2019: 2158-2171; KOMPARASI BANK UMUM SYARIAH DI INDONESIA DAN MALAYSIA DITINJAU DARI RBBR DAN ISLAMICITY PERFORMANCE

Tujuan

Adapun tujuan dari penelitian ini adalah untuk mengetahui apakah terdapat perbedaan Risk-Based Bank Rating dilihat dari aspek risk profile, earning dan capital yang diproksikan dengan FDR, ROA, ROE, dan CAR serta Islamicity Performance yang dilihat dari aspek Profit Sharing Ratio(PSR) dan Zakat Perfomance Ratio (ZPR) pada perbankan syariah di Indonesia dan Malaysia periode 2013-2018.

\section{LANDASAN TEORI DAN PENGEMBANGAN HIPOTESIS}

\section{Kesehatan Bank}

Menurut Ikatan Bankir Indonesia (2016;3), tingkat kesehatan bank merupakan hasil penilaian atas berbagai aspek yang berpengaruh terhadap kondisi atau kinerja suatu bank.

\section{Tata Cara Penilaian Risk-based Bank Rating (RBBR)}

Bank Indonesia telah menetapkan sistem penilaian tingkat kesehatan bank berbasis risiko yakni dalam PBI No.13/1/PBI/2011, peraturan ini menggantikan penillaian CAMELS yang dulunya diatur dalam $\mathrm{PBI}$ No.6/10/PBI/2004.

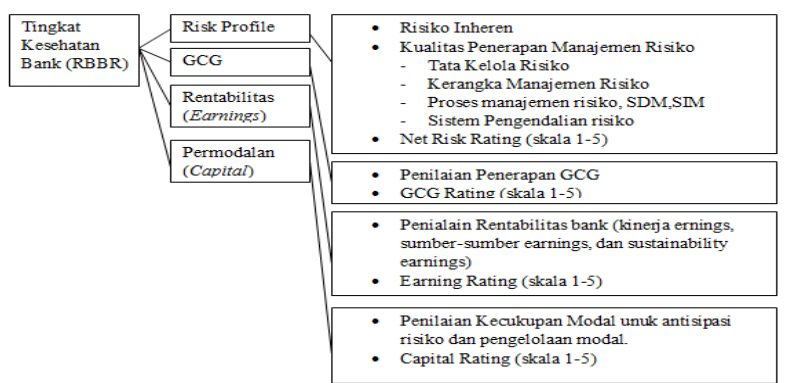

Sumber: Ikatan Bankir Indonesia (2016)
Dalam Ikatan Bankir Indonesia (2016), perangkat setiap faktor risiko dan komposit ditetapkan berdasarkan kerangka analisis yang terstruktur terhadap peringkat setiap factor, dengan memperhatikan materialitas masingmasing fakor, serta mempertimbangkan kemampuan bank dalam menghadapi perubahan kondisi eksternal yang signifikan.

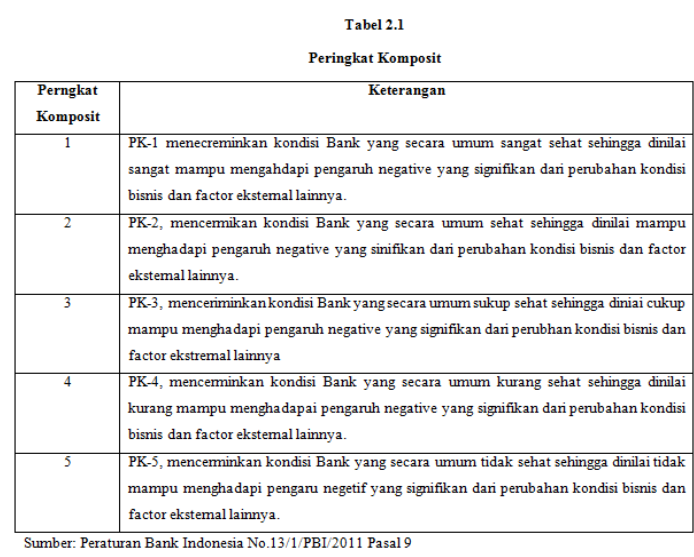

Pengkuran Risk Profile, Earning, dan Capital

1. Profil Risiko (Risk Profile)

Pada penelitian ini, faktor profil risiko diukur dengan risiko likuiditasnya menggunakan Finanacing to Deposits Ratio (FDR). Menurut Mokni et.al (2012) Risiko likuiditas merupakan risiko yang paling penting, kemudian diikuiti oleh risiko ketidakpatuhan syariah dan risiko kredit, sementara risiko pasar dinilai sebagai risiko yang kurang penting diantara risiko lainnya. Risiko likuiditas dapat dihitung menggunakan rasio FDR (Financing to Deposits Ratio), sebagai berikut:

$$
\mathrm{FDR}=\frac{\text { Total Pendanaan }}{\text { Total Dana Pihak Ketiga }} \times 100 \%
$$

Sumber: SE BI 13/30/DPNP/2011 
Herviyani, et al/Jurnal Ekonomi Syariah Teori dan Terapan Vol. 6 No. 11 November 2019: 2158-2171; KOMPARASI BANK UMUM SYARIAH DI INDONESIA DAN MALAYSIA DITINJAU DARI RBBR DAN ISLAMICITY PERFORMANCE

H1: Terdapat perbedaan yang signifikan antara kesehatan bank syariah Indonesia, dan Malaysia dilihat dari rasio Risk profile (FDR).

2. Rentabilitas (Earnings)

Menurut Kasmir $(2016 ; 234)$, rasio rentabilitas sering disebut dengan profitabilitas usaha yang digunakan untuk mengukur tingkat efisiensi usaha dan profiabilitas yang dicapai oleh bank yang bersangkutan.

Salah satu indikator rentabilitas adalah Return On Assets (ROA), rasio ini mengukur efisiensi dari penggunaan aset dalam menghasilkan laba. ROA $=\frac{\text { Laba Sebelum Pajak }}{\text { Rata-Rata Total Aset }} \times 100 \%$

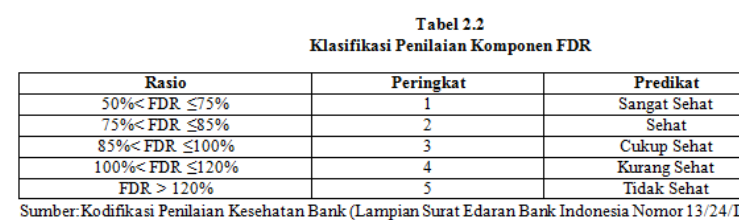

Sumber: SE BI 13/30/DPNP/2011

H2: Terdapat perbedaan yang signifikan antara kesehatan bank syariah Indonesia dan Malaysia dilihat dari rasio Earning (ROA).

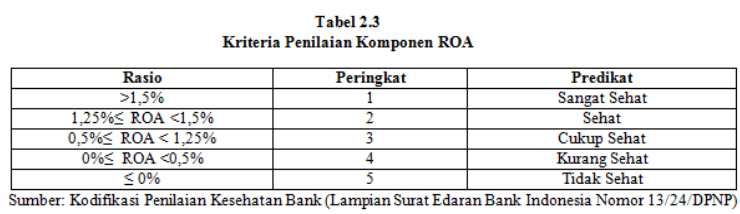

Indikator lain yang bisa digunakan untuk mengukur rentabilitas atau earning adalah rasio Return on Equity (ROE). Menurut Kasmir (2016:204), hasil pengembalian ekuitas atau return on equity atau rentabilitas modal sendiri merupakan rasio untuk mengukur laba bersih sesudah pajak dengan modal sediri.

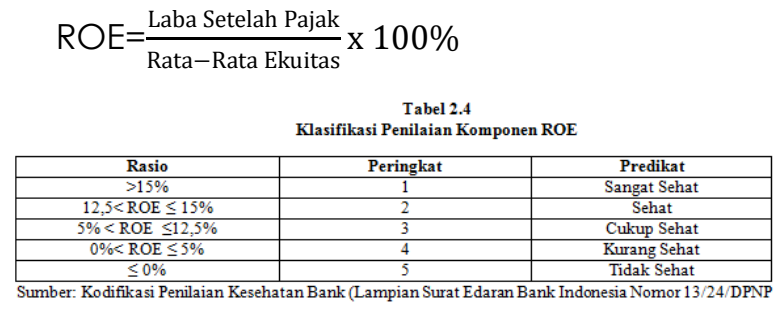

Sumber: SE BI 13/30/DPNP/2011

H3: Terdapat perbedaan yang signifikan antara kesehatan bank syariah Indonesia dan Malaysia dilihat dari rasio Earning (ROE).

3. Permodalan (Capital)

Menurut Karim \& Widyasti(2018), pengukuran dari faktor permodaan termasuk dalam penilaian komponen:

- Kecukupan, komposisi, (tren masa depan) modal serta kemapuan modal bank untuk menutupi aset yang bermasalah.

- Kemampuan bank untuk mempertahankan kebutuhan untuk tambahan modal yang berasal dari laba, rencana modal bank untuk mendukung pertumbuhan bisnis, akses ke sumber modal, dan kinerja kevangan dari pemegang saham untuk meningkatkan modal bank.

Rumus CAR ialah sebagai berikut:

$\mathrm{CAR}=\frac{\text { Modal }}{\text { Aktiva Tertimbang Menurut Risiko (ATMR) }} \times 100 \%$ Tabel 2.5

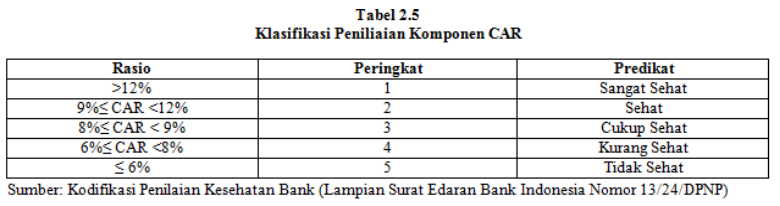

Sumber: SE BI 13/30/DPNP/2011

H4: Terdapat perbedaan yang signifikan antara kesehatan bank syariah Indonesia dan Malaysia dilihat dari rasio Capital (CAR). 
Herviyani, et al/Jurnal Ekonomi Syariah Teori dan Terapan Vol. 6 No. 11 November 2019: 2158-2171; KOMPARASI BANK UMUM SYARIAH DI INDONESIA DAN MALAYSIA DITINJAU DARI RBBR DAN ISLAMICITY PERFORMANCE

\section{Islamicity Performance Index}

Menurut Hameed et al (2004) Islamicity Performance Index merupakan suatu alat ukur yang dikembangkan untuk membantu pada stakeholders yakni deposan, pemegang saham, pemerintah, badan keagamaan, dll untuk mengevauasi kinerja lembaga keuangan Islam.

\section{Pengukuran Islamicity Performance Index}

Untuk mengukur kinerja keislaman pada lembaga keuangan syariah, Hameed et al (2004) dalam penelitiannya telah mengembangkan sebuah index yang dinamakan dengan Islamicity Performance Index, yang didalamnya terdiri dari: (1) profit sharing ratio, (2) zakat performance ratio, (3) equitable distribution ratio, (4) directors-employess welfare ratio, (5) Islamic Investment vs non Islamic Investment, (6) Islamic Income vs non Islamic Income, (7) AAOIFI index. Namun dalam penelitian ini hanya menggunakan dua rasio yang ada di Islamicity Performance Index yakni ProfitSharing Ratio (PSR) dan Zakat Performance Ratio (ZPR).

1. Profit-Sharing Ratio (PSR)

Tujuan utama perbankan syariah ialah pembagian keuntungan (profit sharing). Menurut Yahya\&Agunggunanto (2012), Teori Profit Loss Sharing dibangun sebagai tawaran baru di luar sistem bunga agar tidak adanya diskriminasi atas pembagian risiko dan laba pada pemangku kepentingan. Menurut Aswad (2014), dasar perhitungan profit sharing adalah profit yang diperoleh dari usaha yang dibiayai dengan kredit atau pembiayaan. Maka dari itu, persamaan yang digunakan untuk menghitung PSR ialah:

$$
\text { PSR }=\frac{\text { Mudharabah }+ \text { Musyarakah }}{\text { Total Pembiayaan }} \times 100 \%
$$

Sumber: Hameed et al (2004)

Keterangan:

Mudharabah $=$ pembiayaan mudharabah

Musyarakah = pembiyaan musyarakah Total Pembiayaan $=$ jumlah seluruh pembiyaan yang diberikan (mudharabah, musyarakah, ijarah, qardh, istishna', murabahah, dII)

H5: Terdapat perbedaan yang signifikan antara kinerja keislaman bank syariah Indonesia dan Malaysia dilihat dari PSR.

2. Zakat Peformance Ratio (ZPR) Menurut Hameed et al (2004), zakat merupakan salah satu dari perintah dalam islam. Mengenai besaran zakat perusahaan, dalam Purbasari, dkk (2015), dijelaskan bahwa Undang-Undang zakat juga tidak mengatur secara tegas baik kewajiban maupun besar zakat perusahaan, Undang-Undang zakat masih menganut asas vouluntary (kesukarelaan) dalam pembayaran zakat.

$\mathrm{ZPR}=\frac{\text { Zakat }}{\text { Net Asset }} \times 100 \%$

Sumber: Hameed et al (2004)

Keterangan:

Zakat = Zakat yang dibayarkan oleh bank 
Herviyani, et al/Jurnal Ekonomi Syariah Teori dan Terapan Vol. 6 No. 11 November 2019: 2158-2171; KOMPARASI BANK UMUM SYARIAH DI INDONESIA DAN MALAYSIA DITINJAU DARI RBBR DAN ISLAMICITY PERFORMANCE

Net Asset $=$ Total Asset dikurangi dengan liabilitas

H6: Terdapat perbedaan yang signifikan antara kinerja keislaman bank syariah Indonesia dan Malaysia dilihat dari ZPR

III. METODE PENELITIAN

Pendekatan yang digunakan dalam penelitian ini adalah pendekatan kuantitatif komparatif. Variabel yang digunakan dalam metode RBBR yang digunakan dalam penelitian ini diwakili oleh Risk Profile, Earnings dan Capital yang kemudian variabel ini akan diproksikan dengan FDR, ROA, ROE, dan CAR. Sedangkan pengukuran kinerja keislaman menggunakan 2 rasio yakni Profit Sharing Ratio (PSR) dan Zakat Performance Ratio (ZPR).

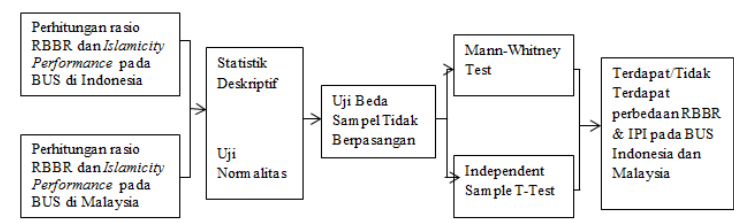

Sumber: Penulis

\section{Teknik Analisis}

Terdapat dua tahap dalam menganalis penelitian ini, yakni statistik deskriptif dan statistik inferensial. Statistik deskriptif menyajikan nilai rata-rata (mean), maximal (max), minimal (min), dan sebagainy. Statistik inferensial adalah teknik statistik yang digunakan untuk menganalisis data sampel dan hasilnya diberlakukan atau digeneralisasikan untuk populasi (Anshori dan Iswati, 2009:123).

Statistik inferensial dalam penelitian ini menggunakan analisis parametric

dengan Independend Sample T-Test dan juga analisis non parametric dengan Mann Whitney Test dengan mengunakan aplikasi SPSS 21.

\section{Uji Normalitas}

Uji normalitas merupakan suatu pengujian yang digunakan untuk mengetahui data terdistribusi dengan normal atau tidak. Uji normalitas pada penelitian ini menggunakan uji Shapiro Wilk dengan tingkat signifikansi (a) sebesar $5 \%$.

Uji T Sampel Independent (Independent Sampe T-Test)

Menurut Sarwono (2018:64) Uji † sampel bebas atau disebut juga uji $\dagger$ sampel independen atau Independent Sample T-Test digunakan untuk membandingkan rata-rata dua kelompok kasus. Untuk membandingkan rata-rata variable dari kedua Negara, dasar pengambilan keputusan Independent Sample T-Test ialah sebagai berikut:

\section{Uji Mann Whitney}

Uji Mann Whitney merupakan uji non parametrik yang setara dengan uji $\dagger$ namun memungkinkan terdapat perbedaan jumlah sampel yang diteliti (Sarwono, 2018:21). Uji Mann whitney memungkinkan untuk digunakan pada data yang tidak terdistribusi secara normal.

\section{HASIL DAN PEMBAHASAN}

Hasil Statistik Deskriptif

Deskriptif Rata-Rata FDR di Indonesia dan Malaysia 
Herviyani, et al/Jurnal Ekonomi Syariah Teori dan Terapan Vol. 6 No. 11 November 2019: 2158-2171; KOMPARASI BANK UMUM SYARIAH DI INDONESIA DAN MALAYSIA DITINJAU DARI RBBR DAN ISLAMICITY PERFORMANCE

Tabel 4.1

Analisis Statistik Deskriptif Rata-Rata Financing to Deposits Ratio (FDR) Bank Syariah di Indonesia dan Malaysia Periode 2013-2018

(Dalam Persentase)

\begin{tabular}{|l|c|l|c|}
\hline $\begin{array}{c}\text { BUS di } \\
\text { Indonesia }\end{array}$ & \multicolumn{1}{|c|}{$\begin{array}{c}\text { BDR } / \mathbf{n} \\
\text { Malaysia }\end{array}$} & \multicolumn{1}{|c|}{ FDR / n } \\
\hline 1. BMI & $87.86 \%$ & 1. BIMB & $80.42 \%$ \\
\hline 2. BSM & $81.27 \%$ & 2. MIBB & $119.48 \%$ \\
\hline 3. BMS & $93.77 \%$ & 3. RHB IBB & $85.04 \%$ \\
\hline 4. BRIS & $93.54 \%$ & 4. SCSB & $190.72 \%$ \\
\hline 5. BSB & $96.50 \%$ & 5. PIBB & $87.15 \%$ \\
\hline 6. BNIS & $91.13 \%$ & 6. KFHB & $142.76 \%$ \\
\hline 7. JBS & $82.69 \%$ & 7. OCBC AB & $91.47 \%$ \\
\hline 8. BCAS & $88.95 \%$ & 8. HSBC & $116.32 \%$ \\
\hline 9. BVS & $90.48 \%$ & 9.ARB & $81.72 \%$ \\
\hline 10. MSI & $177.80 \%$ & 10. CIMB & $90.25 \%$ \\
\hline 11. BPS & $91.44 \%$ & 11. Affin & $90.95 \%$ \\
\hline Mean & $97.77 \%$ & Mean & $106.93 \%$ \\
\hline Max & $177.80 \%$ & Max & $190.72 \%$ \\
\hline Min & $81.27 \%$ & Min & $80.42 \%$ \\
\hline
\end{tabular}

Pada tabel 4.1 terlihat bahwa nilai rata-rata FDR periode 2013-2018 pada Bank Syariah di Indonesia sebesar $97.77 \%$, sedangkan Bank Syariah di Malaysia sebesar $106.93 \%$. Rata-rata rasio FDR yang paling baik dimiliki oleh Bank Syariah di Indonesia dikarenakan semakin tinggi FDR mengindikasikan kesehatan Bank yang semakin buruk.

\section{Deskriptif Rata-Rata ROA Bank Syariah di} Indonesia dan Malaysia

\section{Tabel 4.2}

Analisis Statistik Deskriptif Rata-Rata Return on Asset (ROA)

Bank Syariah di Indonesia dan Malaysia

Periode 2013-2018

(Dalam Persentase)

\begin{tabular}{|l|c|l|c|}
\hline Indonesia & $\sum$ ROA /n & \multicolumn{1}{|c|}{ Malaysia } & $\sum$ ROA / \\
\hline 1. BMI & $0.36 \%$ & 1. BIMB & $1.46 \%$ \\
\hline 2. BSM & $0.72 \%$ & 2. MIIBB & $0.93 \%$ \\
\hline 3. BMS & $1.34 \%$ & 3. RHB IBB & $0.68 \%$ \\
\hline 4. BRIS & $0.65 \%$ & 4. SCSB & $0.38 \%$ \\
\hline 5. BSB & $0.43 \%$ & 5. PIBB & $1.10 \%$ \\
\hline 6. BNIS & $1.37 \%$ & 6. KFHB & $-0.07 \%$ \\
\hline 7. JBS & $-1.90 \%$ & 7. OCBC AB & $1.17 \%$ \\
\hline 8. BCAS & $1.05 \%$ & $\mathbf{8 . ~ H S B C ~}$ & $0.91 \%$ \\
\hline 9. BVS & $0.87 \%$ & 9. ARB & $2.52 \%$ \\
\hline 10. MSI & $-4.09 \%$ & 10. CIMB & $1.02 \%$ \\
\hline 11. BPS & $-1.00 \%$ & 11. Affin & $0.58 \%$ \\
\hline Mean & $-0.02 \%$ & Mean & $0.97 \%$ \\
\hline Max & $1.37 \%$ & Max & $2.52 \%$ \\
\hline Min & $-4.09 \%$ & Min & $-0.07 \%$ \\
\hline
\end{tabular}

Pada tabel 4.2 terlihat bahwa ratarata ROA periode 2013-2018 pada Bank Syariah di Indonesia ialah sebesar $-0.02 \%$ sedangkan pada Bank Syariah Malaysia sebesar $0.97 \%$. Bank Syariah di Malaysia memiliki rata-rata ROA lebih tinggi dibandingkan Indonesia.

Deskriptif Rata-Rata ROE Bank Syariah di Indonesia dan Malaysia

Tabel 4.3

Analisis Statistik Deskriptif Rata-Rata Return on Equity (ROE)

Bank Syariah di Indonesia dan Malaysia

Periode 2013-2018

(Dalam Persentase)

\begin{tabular}{|l|c|l|c|}
\hline $\begin{array}{c}\text { BUS di } \\
\text { Indonesia }\end{array}$ & $\sum$ ROE /n & $\begin{array}{c}\text { BUS di } \\
\text { Malaysia }\end{array}$ & $\sum$ ROE /n \\
\hline 1. BMI & $7.14 \%$ & 1. BIMB & $18.02 \%$ \\
\hline 2. BSM & $7.08 \%$ & 2. MIIBB & $16.46 \%$ \\
\hline 3. BMS & $8.86 \%$ & 3. RHB IBB & $12.13 \%$ \\
\hline 4. BRIS & $5.14 \%$ & 4. SCSB & $8.55 \%$ \\
\hline 5. BSB & $3.51 \%$ & 5. PIBB & $11.69 \%$ \\
\hline 6. BNS & $11.31 \%$ & 6. KFHB & $1.81 \%$ \\
\hline 7. JBS & $-16.00 \%$ & 7. OCBC AB & $12.91 \%$ \\
\hline 8. BCAS & $3.87 \%$ & 8. HSBC & $8.50 \%$ \\
\hline 9. BVS & $-7.07 \%$ & 9.ARB & $17.37 \%$ \\
\hline 10. MSI & $-10.14 \%$ & 10. CIMB & $13.10 \%$ \\
\hline 11. BPS & $-12.40 \%$ & 11. Affin & $5.97 \%$ \\
\hline Mean & $0.12 \%$ & Mean & $11.50 \%$ \\
\hline Max & $11.31 \%$ & Max & $18.02 \%$ \\
\hline Min & $-16.00 \%$ & Min & $1.81 \%$ \\
\hline
\end{tabular}

Pada tabel 4.3 terlihat bahwa ratarata ROE Bank Syariah di Indonesia bernilai 0,12\% Sedangkan pada Bank Syariah di Malyasia adalah $11.50 \%$. Bank Syariah di Malaysia memiliki rata-rata ROE yang lebih baik dibandingkan dengan Bank Syariah di Indonesia.

\section{Deskriptif Rata-Rata CAR Bank Syariah di} Indonesia dan Malaysia

Tabel 4.4

Analisis Statistik Deskriptif Rata-Rata Capital Adequacy Ratio (CAR) Bank Syariah di Indonesia dan Malaysia Periode 2013-2018

(Dalam Persentase)

\begin{tabular}{|l|c|l|c|}
\hline $\begin{array}{c}\text { BUS di } \\
\text { Indonesia }\end{array}$ & $\sum$ CAR / & $\begin{array}{c}\text { BUS di } \\
\text { Malaysia }\end{array}$ & $\sum$ CAR / \\
\hline 1. BMI & $13.75 \%$ & 1. BMB & $15.38 \%$ \\
\hline 2. BSM & $14.65 \%$ & 2. MIIBB & $18.03 \%$ \\
\hline 3. BMS & $19.54 \%$ & 3. RHB IBB & $15.00 \%$ \\
\hline 4. BRIS & $18.59 \%$ & 4. SCSB & $19.02 \%$ \\
\hline 5. BSB & $16.46 \%$ & 5. PIBB & $14.20 \%$ \\
\hline 6. BNS & $17.11 \%$ & 6. KFHB & $26.13 \%$ \\
\hline 7. JBS & $17.88 \%$ & 7. OCBC AB & $16.71 \%$ \\
\hline 8. BCAS & $29.45 \%$ & 8. HSBC & $16.96 \%$ \\
\hline 9. BVS & $17.86 \%$ & 9.ARB & $20.92 \%$ \\
\hline 10. MSI & $74.07 \%$ & 10. CIMB & $16.05 \%$ \\
\hline 11. BPS & $19.94 \%$ & 11. Affin & $15.27 \%$ \\
\hline Mean & $23.57 \%$ & Mean & $17.61 \%$ \\
\hline Max & $74.07 \%$ & Max & $26.13 \%$ \\
\hline Min & $13.75 \%$ & Min & $14.20 \%$ \\
\hline
\end{tabular}


Herviyani, et al/Jurnal Ekonomi Syariah Teori dan Terapan Vol. 6 No. 11 November 2019: 2158-2171; KOMPARASI BANK UMUM SYARIAH DI INDONESIA DAN MALAYSIA DITINJAU DARI RBBR DAN ISLAMICITY PERFORMANCE

Pada tabel 4.4 terlihat bahwa dari nilai rata-rata CAR Bank Syariah di Indonesia sebesar $23.57 \%$, sedangkan pada Bank Syariah di Malaysia sebesar 17.61\%. Bank Syariah di Indonesia memiliki nilai rata-rata CAR yang lebih tinggi dibandingkan dengan rata-rata CAR pada Bank Syariah di Malaysia.

Deskriptif Rata-Rata PSR Bank Syariah di Indonesia dan Malaysia

Tabel 4.5

Analisis Statistik Deskriptif Rata-Rata Profit Sharing Ratio (PSR)

Bank Syariah di Indonesia dan Malaysia

Periode 2013-2018

(Dalam Persentase)

\begin{tabular}{|l|c|l|c|}
\hline $\begin{array}{c}\text { BUS di } \\
\text { Indonesia }\end{array}$ & $\sum$ PSR / $\mathbf{n}$ & $\begin{array}{c}\text { BUS di } \\
\text { Malaysia }\end{array}$ & $\sum$ PSR / $\mathbf{n}$ \\
\hline 1. BMI & $51.85 \%$ & 1. BIMB & $0.00 \%$ \\
\hline 2.BSM & $27.52 \%$ & 2. MIIBB & $3.85 \%$ \\
\hline 3. BMS & $4.57 \%$ & 3. RHB IBB & $24.13 \%$ \\
\hline 4. BRIS & $32.31 \%$ & 4. SCSB & $53.50 \%$ \\
\hline 5. BSB & $49.18 \%$ & 5. PIBB & $30.43 \%$ \\
\hline 6. BNIS & $20.85 \%$ & 6. .FHB & $4.10 \%$ \\
\hline 7. JBS & $24.95 \%$ & 7. OCBC AB & $5.65 \%$ \\
\hline 8. BCAS & $44.61 \%$ & 8. HSBC & $37.85 \%$ \\
\hline 9.BVS & $64.33 \%$ & 9.ARB & $0.00 \%$ \\
\hline 10. MSI & $11.30 \%$ & 10. CIMB & $0.00 \%$ \\
\hline 11. BPS & $69.91 \%$ & 11. Affin & $18.91 \%$ \\
\hline Mean & $36.49 \%$ & Mean & $16.22 \%$ \\
\hline Max & $69.91 \%$ & Max & $53.50 \%$ \\
\hline Min & $4.57 \%$ & Min & $0.00 \%$ \\
\hline
\end{tabular}

Pada tabel 4.5 terlihat bahwa nilai rata-rata Profit Sharing Ratio (PSR) pada Bank Syariah di Indonesia sebesar 36,49\%, sedangkan pada Bank Syariah di negara Maaysia sebesar 16,22\%. Bank Syariah di Indonesia memiliki nilai rata-rata PSR lebih tinggi jika dibandingkan dengan Malaysia.

Deskriptif Rata-Rata ZPR Bank Syariah di Indonesia dan Malaysia
Tabel 4.6

Analisis Statistik Desriptif Rata-Rata Zakat Performance Ratio (ZPR)

Bank Syariah di Indonesia dan Malaysia Periode 2013-2018

(Dalam Persentase)

\begin{tabular}{|l|c|l|c|}
\hline $\begin{array}{c}\text { BUS di } \\
\text { Indonesia }\end{array}$ & $\sum$ ZPR / n & $\begin{array}{c}\text { BUS di } \\
\text { Malaysia }\end{array}$ & $\sum$ ZPR /n \\
\hline 1. BMI & $0.03 \%$ & 1. BIMB & $0.27 \%$ \\
\hline 2. BSM & $0.05 \%$ & 2. MIBB & $0.21 \%$ \\
\hline 3. BMS & $0.04 \%$ & 3. RHB IBB & $0.10 \%$ \\
\hline 4. BRIS & $0.03 \%$ & 4. SCSB & $0.00 \%$ \\
\hline 5. BSB & $0.00 \%$ & 5. PIBB & $0.01 \%$ \\
\hline 6. BNIS & $0.07 \%$ & 6. KFHB & $0.00 \%$ \\
\hline 7. JBS & $0.01 \%$ & 7. OCBC AB & $0.00 \%$ \\
\hline 8. BCAS & $0.00 \%$ & 8. HSBC & $0.00 \%$ \\
\hline 9. BVS & $0.01 \%$ & 9.ARB & $0.12 \%$ \\
\hline 10. MSI & $0.00 \%$ & 10. CIMB & $0.01 \%$ \\
\hline 11. BPS & $0.12 \%$ & 11. Affin & $0.51 \%$ \\
\hline Mean & $0.03 \%$ & Mean & $0.11 \%$ \\
\hline Max & $0.12 \%$ & Max & $0.51 \%$ \\
\hline Min & $0.00 \%$ & Min & $0.00 \%$ \\
\hline
\end{tabular}

Pada tabel 4.6 terihat bahwa nilai rata-rata Zakat Performance Ratio (ZPR) pada Bank Syariah di Indonesia sebesar $0.03 \%$, sedangkan pada Bank Syariah di Malaysia sebesar $0.11 \%$. Nilai rata-rata rasio ZPR pad Bank Syariah di Malaysia lebih tinggi dibandingkan dengan Indonesia.

\section{Uji Normalitas}

Berikut data uji Normalitas pada Bank Syariah di Indonesia dan Malaysia dapat dilihat pada tabel berikut ini:

\begin{tabular}{|c|c|c|c|c|c|c|}
\hline \multicolumn{7}{|c|}{$\begin{array}{l}\text { Uji Normalitas Data Masing-Masing Variabel } \\
\text { Bank Syariah di Indonesia dan Malaysia } \\
\text { Periode 2013-2018 }\end{array}$} \\
\hline Variabel & Bank & df & Statistics & Sig & Keterangan & Distribusi Data \\
\hline \multirow{2}{*}{ FDR } & Indonesia & 11 & 0.483 & 0.000 & Tidak Nomal & \multirow{2}{*}{ Tidak Normal } \\
\hline & \begin{tabular}{|l|} 
Malaysia \\
\end{tabular} & 11 & 0.767 & 0.003 & Tidak Normal & \\
\hline \multirow{2}{*}{ ROA } & Indonesia & 11 & 0.844 & 0.036 & Tidak Nomal & \multirow{2}{*}{ Tidak Normal } \\
\hline & \begin{tabular}{|l|} 
Malaysia \\
\end{tabular} & 11 & 0.924 & 0.349 & Normal & \\
\hline \multirow{2}{*}{ ROE } & Indonesia & 11 & 873 & 0.084 & Normal & \multirow{2}{*}{ Normal } \\
\hline & Malaysia & 11 & 0.943 & 0.562 & Normal & \\
\hline \multirow{2}{*}{ CAR } & Indonesia & 11 & 0.535 & 0.000 & Tidak Normal & \multirow{2}{*}{ Tidak Normal } \\
\hline & \begin{tabular}{|l|} 
Malaysia \\
\end{tabular} & 11 & 0.834 & 0.027 & Tidak Nomal & \\
\hline \multirow{2}{*}{ PSR } & \begin{tabular}{|l|} 
Indonesia \\
\end{tabular} & 11 & 0.966 & 0.843 & Normal & \multirow{2}{*}{ Tidak Normal } \\
\hline & \begin{tabular}{|l|} 
Malaysia \\
\end{tabular} & 11 & 0.854 & 0.048 & Tidak Nomal & \\
\hline \multirow{2}{*}{$\mathrm{ZPR}$} & \begin{tabular}{|l|} 
Indonesia \\
\end{tabular} & 11 & 0.835 & 0.027 & Tidak Nomal & \multirow{2}{*}{ Tidak Normal } \\
\hline & Malaysia & 11 & 0.758 & 0.003 & Tidak Normal & \\
\hline
\end{tabular}

Pada tbel 4.7 menjelaskan bahwa pada uji normalitas yang telah dilakukan, disimpulkan bahwa hanya variable ROE yang datanya terdistribusi secara normal sehingga uji hipotesis nya dilakukan dengan menggunakan Independent 
Herviyani, et al/Jurnal Ekonomi Syariah Teori dan Terapan Vol. 6 No. 11 November 2019: 2158-2171; KOMPARASI BANK UMUM SYARIAH DI INDONESIA DAN MALAYSIA DITINJAU DARI RBBR DAN ISLAMICITY PERFORMANCE

Sample T-Test. Sedangkan variabel FDR, ROA, CAR, PSR, dan ZPR menggunakan uji Mann-Whitney karena data yang dimiliki variabel tersebut tidak terdistribusi secara normal.

\section{Uji Beda}

\section{Uji Beda Variabel FDR}

\begin{tabular}{c|c|c|c|c|}
\multicolumn{5}{c}{ Tabel 4.8 } \\
Uji Mann-Whitney \\
\multicolumn{5}{c|}{ Variabel Financing to Deposits Ratio (FDR) } \\
\hline Variabel & Negara & $\mathbf{N}$ & Sig & Keterangan \\
\hline FDR & Indonesia & 11 & \multirow{2}{*}{0.622} & $\begin{array}{c}\text { Ho diterima } \\
\text { (Tidak terdapat perbedaan) }\end{array}$ \\
\cline { 2 - 3 } & Malaysia & 11 & &
\end{tabular}

Berdasarkan tabel 4.8 pada Mann Whitney Test nilai signifikansi dari variabel Financing to deposits Ratio (FDR) adalah 0,622 atau lebih besar dari 0,05 sehingga dapat dinyatakan bahwa Hipotesis nol diterima yakni tidak terdapat perbedaan signifikan dari variabel FDR antar Bank Syariah di Indonesia dan Malaysia pada periode 2013-2018.

\section{Uji Beda Variabel ROA}

Tabel 4.9
Uji Mann Whitney
Variabel Return on Asset (ROA)
\begin{tabular}{|c|c|c|c|c|}
\hline \multicolumn{1}{c|}{ Variabel } & Negara & N & Sig & Keterangan \\
\hline \multirow{2}{*}{ ROA } & Indonesia & 11 & 0.094 & $\begin{array}{c}\text { Ho diterima } \\
\text { (Tidak terdapat perbedaan) }\end{array}$ \\
\cline { 2 - 4 } & Malaysia & 11 & 0.99 &
\end{tabular}

Berdasarkan tabel 4.9 pada Mann Whitney Test, diketahui bahwa niai signifikansi dari variabel yang telah diuji daah sebesar 0,094 atau lebih besar dari 0,05 . Sehingga dapat dinyatakan bahwa tidak terdapat perbedaan signifikan variabel ROA pada Bank Syariah di Negara Indonesia dan Malaysia pada periode 2013-2018.

\section{Uji Beda Variabel ROE}

Tabel 4.10
$\begin{gathered}\text { Independent Sample T-Test } \\
\text { Variabel Return on Equity (ROE) }\end{gathered}$
\begin{tabular}{|c|c|c|c|c|}
\hline Variabel & Negara & $\mathrm{N}$ & Sig & Keterangan \\
\hline \multirow{2}{*}{ ROE } & Indonesia & 11 & 0.003 & $\begin{array}{c}\text { Ho ditolak } \\
\text { (Terdapat perbedaan) }\end{array}$ \\
\cline { 2 - 4 } & Malaysia & 11 & 0.004 &
\end{tabular}

Berdasarkan tabel 4.10 hasil uji beda Independent Sample T-Test diketahui bahwa nilai signifikansi dari variable yang ada pada Indonesi adalah 0,003 dan pada Malaysia adalah 0,004 atau lebih kecil dari 0,05. Maka dari itu, dapat dinyaakan bahwa terdapat perbedaan yang signifikan variabel ROE pada Bank Syariah di Negra Indonesia dan Malaysia pada periode 2013-2018.

\section{Uji Beda Variabel CAR}

\begin{tabular}{c|c|c|c|c|}
\multicolumn{5}{c}{ Tabel 4.11 } \\
Uji Mann Whitney \\
Variabel Capital Adequacy Ratio (CAR) \\
\cline { 2 - 3 } \multicolumn{1}{c|}{} \\
\hline Variabel & Negara & N & Sig & Keterangan \\
\hline \multirow{2}{*}{ CAR } & Indonesia & 11 & \multirow{2}{*}{0.341} & $\begin{array}{c}\text { Ho diterima } \\
\text { (Tidak terdapat perbedaan) }\end{array}$ \\
\cline { 2 - 3 } & Malaysia & 11 & &
\end{tabular}

Berdasarkan tabel 4.11 hasil uji beda Mann Whitney diketahui bahwa nilai signifikansi dari Variabel CAR yang telah diteliti ialah sebesar 0,0341 atau lebih bear dari 0,05 . Maka dari itu, dapat dinyataan bahwa tidak terdapat perbedaan signifikan variabel CAR pada Bank Syariah di Indonesia dan Malaysia pada periode 2013-2018.

\section{Uji Beda Variabel PSR}

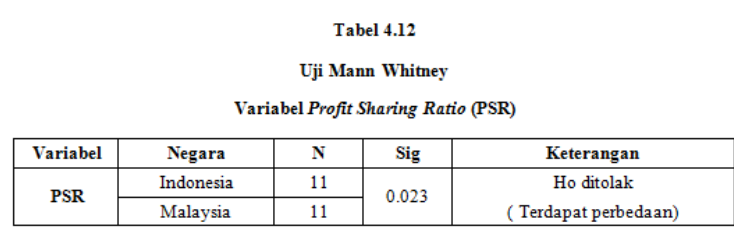

Berdasarkan tabel 4.12 hasil uji beda Mann Whitney diketahui bahwa nilai signifikansi dari variabel ini adalah 0,023 yakni lebih kecil dari 0,05. Maka dari itu 
Herviyani, et al/Jurnal Ekonomi Syariah Teori dan Terapan Vol. 6 No. 11 November 2019: 2158-2171; KOMPARASI BANK UMUM SYARIAH DI INDONESIA DAN MALAYSIA DITINJAU DARI RBBR DAN ISLAMICITY PERFORMANCE

dapat dinyatakan bahwa Hipotesis nol diterima dan menunujukkan adanya perbedaan signifikan variabel PSR antar Bank Syariah di Indonesia dan Malaysia pada periode 2013-2018.

Uji Beda Variabel ZPR

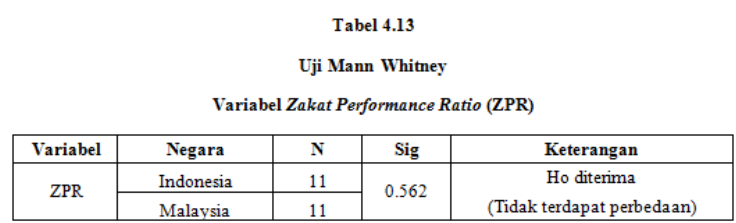

Berdasarkan tabel 4.13 hasil uji beda Independent Sample T-Test, nilai signifikansi ZPR yang diperoleh ialah 0,562. Nilai signifikansi variabel ZPR tersebut lebih besar dari 0,05. Sehingga dapat dinyatakan Hiopetesis nol diterima yakni tidak terdapat perbedaan signifikan variabel ZPR antar Bank Syariah di Indnesia dan Malaysia selama periode 2013-2018

\section{Inteprestasi Hasil dan Pembahasan}

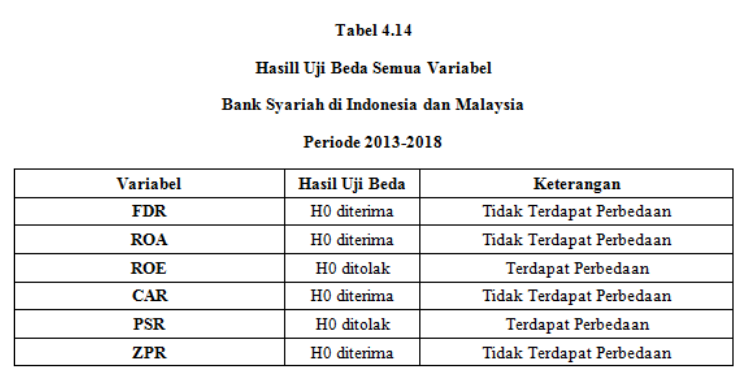

Financing to Deposits Ratio (FDR)

Dari hasil uji Mann Whitney, diperoleh hasil signifikasi sebesar 0,622, lebih besar dari 0,05 sehingga $\mathrm{HI}$ ditolak dan HO diterima. Hasil ini menunjukkan bahwa tidak terdapat perbedaan signifikan antara FDR pada Bank Syariah di Indonesia dan Bank Syariah di Malaysia. $\mathrm{Hal}$ ini sesuai dengan hasil penelitian Hendratmi, dkk (2017) bahwasannya tidak terdapat perbedaan yang signifikan antara kesehatan Bank Syariah di Indonesia dengan Bank Syariah di Malaysia diukur menggunakan rasio FDR.

\section{Return on Asset (ROA)}

Dari hasil uji Mann Whitney, diperoleh hasil signifikansi sebesar 0.094, lebih besar dari 0,05 sehingga $\mathrm{HI}$ ditolak dan HO diterima. Hasil ini menunjukkan bahwa tidak terdapat perbedaan yang signifikan pada variabel ROA.Hal ini sesuai dengan penelitian Puspita \& Saryadi (2018) bahwasannya tidak terdapat perbedaan yang signifikan antara kesehatan Bank Syariah Indonesia dan Malaysia dilihat dari ROA.

\section{Return on Equity (ROE)}

Dari hasil Independent Sample TTest diperoleh hasil signifikansi sebesar 0.003 untuk Bank Syariah di Indonesia dan 0,004 untuk Bank Syariah di Malaysia, lebih kecil dari 0,05 sehingga $\mathrm{HO}$ ditolak dan $\mathrm{Hl}$ diterima. Jadi, terdapat perbedaan kesehatan Bank Syariah di Indonesia dengan Bank Syariah di Malaysia pada variabel ROE. Hal ini sejalan dengan penelitian Baldina (2017), bahwa terdapat perbedaan dari perputaran pendapatan yang didapatkan dibandingkan ekuitas yang dimiliki oleh Bank Syariah devisa dan non devisa di Indonesia.

\section{Capital Adequacy Ratio (CAR)}

Dari hasil uji Mann Whitney pada variabel CAR yang diteliti, signifikansi nya bernilai 0,341. Angka signifikansi CAR ini lebih besar dari 0,05. Hal ini menunjukkan bahwa HO diterima dan tidak terdapat perbedaan yang signifikan dari variabel 
Herviyani, et al/Jurnal Ekonomi Syariah Teori dan Terapan Vol. 6 No. 11 November 2019: 2158-2171; KOMPARASI BANK UMUM SYARIAH DI INDONESIA DAN MALAYSIA DITINJAU DARI RBBR DAN ISLAMICITY PERFORMANCE

CAR yang dimiliki oleh Bank Syariah di Indonesia dengan Bank Syariah di Malaysia. Hal ini sejalan dengan penelitian yang dilakuakn oleh Pupita \& Saryadi (2018) yang menguji tingkat kesehatan Bank Syariah di Indonesia dan Malaysia dan menemukan bahwa CAR pada Bank Syariah di kedua negara tersebut tidak terdapat perbedaan yang signifikan.

\section{Profit Sharing Ratio (PSR)}

Hasil analisis deskriptif dari Bank Syariah di Indonesia dan Bank Syariah di Malaysia bisa dilihat bahwa rasio PSR yang dimiliki oleh Bank Syariah di Indonesia yakni sebesar $36,49 \%$. Sedangkan pada Bank Syariah di Malaysia rata-rata rasio PSR sebesar 16.22\%. Nilai rata-rata rasio PSR yang dimiliki oleh Bank Syariah di Indonesia lebih tinggi jika dibndingkan dengan rata-rata rasio PSR pada Bank Syariah di Malaysia.

Hasil uji Mann Whitney yang telah dilakukan, dapat dilihat bahwa nilai signifikansi variabel PSR yang telah diuji ialah sebesar 0,023. Angka ini lebih kecil daripada 0,05 dan mengindikasikan bahwa Hipotesis nol dalam penelitian ini ditolak dan terdapat perbedaan yang signifikan antara PSR Bank Syariah di Indonesia dibandingkan dengan Malaysia. Penelitian ini mendukung penelitian ynag dilakukan oleh Hendratmi (2017) yang menyebutkan tedapat perbedaan rasio PSR pada Bank Syariah di Indonesia dan Malaysia. Penelitian Baldina (2017) menunjukkan hasil yang sama yakni terdapat perbedaan signifikansi rasio PSR pada Bank Syariah devisa dan Bank Syariah non devisa di Indonesia.

\section{Zakat Performance Ratio (ZPR)}

Hasil analisis deskriptif dari Bank Syariah di Indonesia dan Malaysia, menyatakan nilai tertinggi rasio ZPR dimiliki oleh Bank Syariah di Malaysia sebesar $0,11 \%$. Nilai rata-rata tersebut lebih tinggi dibandingkan dengan Bank Syariah di Indonesia ynag hanya sebesar $0,03 \%$. Hasil uji Mann Whitney yang telah dilakukan, menyatakan bahwa dari Bank Syariah di Indonesai dan Malaysia pada periode 2013-2018, memiliki nilai signifikansi sebesar 0,562 yakni lebih besar dari 0,05. Maka, hal ini menunjukkan bahwa tidak terdapat perbedaan yang signifikan rasio ZPR pada Bank Syariah di Indonesia dan Bank Syariah di Malaysia. Penelitian ini mendukung penelitian terdahulu yang telah dilakukan oleh Lutfiandari \& Fitrisia (2016), bahwa tidak terdapat perbedaan zakat performance ratio pada Bank Umum Syariah di Indonesia periode 2011 2014.

Menurut BAZNAZ dalam ON Zakat Perusahaan:Ketentuan Aset Zakat, Non Zakat, dan Pengurang Zakat (2019), Harta yang diinvestasikan dalam syirkah dengan mengandalkan usaha manusia (pekerjaan) ynag bertujuan untuk memperoleh keuntungan dan pertumbuhn merupakan salah satu harta wajib zakat. Pada BUS di Indonesia dan Malaysia masih terdapat beberapa Bank yang tidak mengeluarkan zakat sesuai ketentuan pada umumnya. Beberapa 
Herviyani, et al/Jurnal Ekonomi Syariah Teori dan Terapan Vol. 6 No. 11 November 2019: 2158-2171; KOMPARASI BANK UMUM SYARIAH DI INDONESIA DAN MALAYSIA DITINJAU DARI RBBR DAN ISLAMICITY PERFORMANCE

Bank Syariah di kedua negara tersebut didapati ZPR nya masih 0,00\%. Dalam hal ini, Bank Syariah di Indonesia dan Malaysia masih ada yang belum menjalankan kewajiban membayar zakat atas harta dari usahanya.

\section{Simpulan dan Saran}

Terdapat perbedaan Risk-based Bank Rating dari segi ROE dan Islamicity performance dari segi PSR pada Bank Syariah di Indonesia dan Malaysia periode 2013-2018. Sedangkan tidak terdapat perbedaan FDR, ROA, CAR, dan ZPR pada Bank Syariah di Indonesia dan Malaysia periode 2013-2018.

\section{DAFTAR PUSTAKA}

Ascarya; Diana, Y. (2010). Bank Syariah: Gambaran Umum PUSAT. In Pusat Pendidikan dan Studi Kebanksentralan (PPSK) Bank Indonesia (Vol. 14). Retrieved from

Aswad, M. (2014). Analisis Bagi Hasil Financing Dalam Perbankan Syariah. An-Nisbah: Jurnal Ekonomi Syariah, 1 (1).

Baldina, Z. (2017). Analisis perbandingan Bank Syariah Non Devisa dan bank Syaraiah Devisa ditinjau dari Kinerja Fungsi Bisnis dan Fungsi Sosial dengan Metode RGEC dan Sharia Conformity Indicator Periode 2011 2015. Ekonomi Syariah Teori Dan Terapan, 4.

BAZNAZ. (2019). Zakat Perusahaan : Ketentuan Aset Zakat, Non Zakat dan Pengurang zakat.

Hendratmi, A., Sukmaningrum, P. S., \&
Hasib, F. F. (2017). Comparative Analysis between Islamic Banks in Indonesia and Malaysia Using RGEC Method and Sharia Conformity Indicator Period 20112015. ICIEBP 2017-1st International Conference on Islamic Economics, Business Philantrophy, (Iciebp 2017), 200-206.

IBI. (2016). Manajemen Kesehatan Bank Berbasis Risiko. Jakarta: PT Gramedia Pustaka Utama.

Karim, A., Rachmawati, W., \& Widyaswati, R. (2018). THE ANALYSIS OF SHARIA BANKS SOUNDNESS LEVEL USING RGEC METHOD. Economics \& Business Solutions Journal, 1(1), 112.

Kasmir. (2016). Analisis Laporan Keuangan. Depok: PT. Raja Grafindo Persada.

Lutfiandari, H. ayu, \& Fitrisia, D. (2016). Analisis Tren dan Perbandingan Rasio Islamicity Performance pada Bank Syariah Mandiri, Bank Muamalat Indonesia, Bank Bri Syariah dan Bank BNI Syariah periode 2011 1-2014. 430-443.

Mansour, W., Ben Abdelhamid, M., Masood, O., \& Niazi, G. S. K. (2010). Islamic banking and customers' preferences: the case of the UK. Qualitative Research in Financial Markets, 2(3), 185-199.

Mokni, R. B. S., Echchabi, A., Azouzi, D., \& Houssem, R. (2012). Risk management tools practiced in Islamic banks : evidence in MENA 
Herviyani, et al/Jurnal Ekonomi Syariah Teori dan Terapan Vol. 6 No. 11 November 2019: 2158-2171; KOMPARASI BANK UMUM SYARIAH DI INDONESIA DAN MALAYSIA DITINJAU DARI RBBR DAN ISLAMICITY PERFORMANCE

region. 5(1), 77-97.

Purbasari Indah, Encik Muhammad Fauzan, A. (2015). Alokasi ,Distribusi Zakat Dan Dana Tanggung Jawab Sosial Di Perbankan Syariah. Masalah-Masalah Hukum, Vol. 44, p. 140.

Radzi, R. M., \& Lonik, K. A. T. (2016). Islamic Banks' Risks: It's Rating Methodology and Shariah Assessment Solutions. Journal of Islamic Banking and Finance, 4(2), 48-60.

Rama, A. (2017). Analisis Deskriptif Perkembangan Perbankan Syariah Di Inggris (2004-2016). The Journal of Tauhidinomics, 1 (2), 105-123.

Saryadi, P. \&. (2018). Uji Beda Tingkat Kesehatan Bank antara Perbakan Syariah Indonesia dengan Perbankan Syariah Malaysia.
Diponegoro Journal of Social and Political,

Shahul Hameed, Ade wirman, Bakhtiar Alrazi, Mohd Nazli, N. and S. P. (2004). ALTERNATIVE DISCLOSURE \& PERFORMANCE MEASURES FOR ISLAMIC. (International Islamic University Malaysia).

Sidiq, I., \& Reskino. (2016). Zakat and Islamic Corporate Social Responsibility: Do These Effect the Performance of Sharia Bank. Shirkah Journal of Economic and Business, 1 (2).

Undang-Undang. (2008). Perbankan Syariah. 153-164.

Yahya, M., \& Yusuf, E. (2012). Teori Bagi Hasil (Profit and Loss Sharing) Dan Perbbankan Syariah Dalam Ekonomi Syariah. Jurnal Dinamika Ekonomi Pembangunan, 1 (1), 65. 